高分子編文集 (Kobunshi Ronbunshu), Vol. 43, No. 2, pp. 63-69 (Feb., 1986)

\title{
アルキル鋇をもつシラン化合物の磁性粒子への吸落兴功と 磁性怜膜中における粒子の分散・配向学動
}

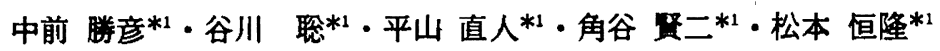

(受付 1985 年 8 月 8 日・榲終了 1985 年 9 月 25 日)

\begin{abstract}
要 旨 アルキル销をもつシラン化合物により $\gamma-\mathrm{Fe}_{2} \mathrm{O}_{3}$ の表面処理を行い，その処理が粒子の分

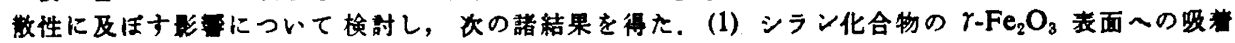
举轨は Langmuir 型を示した。 (2) $\gamma-\mathrm{Fe}_{2} \mathrm{O}_{3}$ 表面をシラン化合物で処理することにより，親水性官 能基をむつボリマーあるいはもたないボリマーのいずれをバインダーとして用いても，粒子の高分散 化が可能であった。 また，その時のシラン化合物の処理贯住 $\gamma-\mathrm{Fe}_{2} \mathrm{O}_{3}$ に対して約 $2 \mathrm{wt} \%$ が遥して おり，シラン化合物のアルキル鎖の長さは宸秦数 8 以上が䢗していた。
\end{abstract}

\section{1 㒂 豆}

近年, 磁気テープの技術動向は記録の高密度化が指向 されている゙。. そのためには，磁性粒子をCo 被着型 $r$ $\mathrm{Fe}_{2} \mathrm{O}_{3}$ やメタル粒子などの高保磁力型ののにし, これ らの粒子を染膜中でより高分散、高配向，高充てんさせ ることが必要である2)，我々は，これまでに，磁性粒子 の分散, 眍向, 充てん性を、高分子バインダーと磁性粒 子との相互作用といら筧点より種々検討を行い，道量の 親水性官能基をるつボリマーがパイン゙ーとして有用で あることを明らかにしてきだ) -8).

ところで，有機一無機系蕧合材料扎いて最近よく用 いられているカップンング剂は，無機物啠と有機マトリ ックスとの界面を改質し，両者間の親和性を向上させ る, あるいは，化学結合により一体化させる効果があ

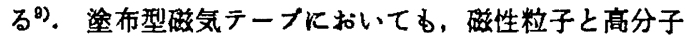
バインダーよりなる有機－無機系複合材料であるので, カップリング剂の適用に上り粒子の高分散化などの効果 が期待される. しかしながら、これまで磁気テーブの分 野にカップリンク郕が応用された研究報告ははとんどな い.

そこで，本研究では，一方にアルキル鎖をもつシラン カップリング剂を用いて磁性粒子の表面を処理し，その シランカッブリング剤の吸着举動が磁性粒子の分散性に 及ぼす影篔について検討した。

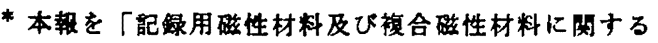
研究 第 12 報」とする。

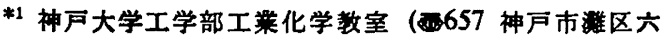
甲台町 1)

\section{2 实唤方法}

\section{1 试料}

磁性粒子としては，長さ $0.4 \mu \mathrm{m}$, 軸比 $1 / 9$ の針状 $\gamma-\mathrm{Fe}_{2} \mathrm{O}_{3}$ 粒子を用いた， ハインダーには，親水性官能基 を有するものとして塩化ビニル一酢酸ビニルービニルアル コール共重合体 (P(VC-VAC-VAL)) 及び，親水性官 能基をすたないるのとして塩化ビニルー酢酥ビニル共重 合体 (P(VC-VAC)) を用いた. Table 1 には，これら のポリマーの諸性質を示した．表面処理剤としては，フ ルキル鎖を有するシラン化合物 6 種類を用いた. Table 2 Kは，これらの化学式を示した。

\section{$2.2 \gamma-\mathrm{Fe}_{2} \mathrm{O}_{3}$ の表面処理}

表面処理は, $\gamma-\mathrm{Fe}_{2} \mathrm{O}_{3} 300 \mathrm{~g}$ を所定灌度のンラン化合 物のトルエン溶液 $1500 \mathrm{~cm}^{8}$ と混合し，木モミキサー (特殊機化工業 (株) 製) を用いて1 時間かくはんした後， ろ過及び乾燥した。なお乾燥は，常温で 48 時間放海 し, その後 $100^{\circ} \mathrm{C} て ゙ 1$ 時間行った.

\section{3 ポリマー吸首目の测定}

ポリマーの吸着甼は， $\gamma-\mathrm{Fe}_{2} \mathrm{O}_{3} 2.0 \mathrm{~g}$ を所定濩度のポ リマー溶液 $20 \mathrm{~cm}^{3}$ に分散させ, $30^{\circ} \mathrm{C} て ゙ 24$ 時間振と 5 後 48 時間静圈し, 液相の澧度变化を乾燥重量法によ り測定して求めた。 なお，溶媒にはメチルイソブチルケ トン/トルエンの容量比 1:1 混合溶媒を用いた.

\section{4 シラン化合物一磁性粒子閌相互作用の界面化学的} 鲆価

シラン化合物の吸着量は 2 通りの方法により測定し た. 一方は, $\gamma-\mathrm{Fe}_{2} \mathrm{O}, 2.0 \mathrm{~g}$ を所定港度のシラン化合物 溶液 $20 \mathrm{~cm}^{3}$ に分散させ， $30^{\circ} \mathrm{C}$ で 24 時間振と5後 200 時間静置し, 液相の濩度変化を乾燥重量法により㨽定し 
中前・谷川・平山・角谷・松本

Table 1. Characteristics of polymers used

\begin{tabular}{|c|c|c|c|c|c|c|}
\hline \multirow{2}{*}{ Polymers } & \multicolumn{3}{|c|}{ Molecular weight") } & \multicolumn{3}{|c|}{ Functional groups ${ }^{b}$ (wt $\left.\%\right)$} \\
\hline & $M_{n} \times 10^{-4}$ & $M_{w} \times 10^{-1}$ & $M_{w} / M_{n}$ & $-\mathrm{Cl}$ & $-\mathrm{OCOCH}_{8}$ & $-\mathrm{OH}$ \\
\hline$P(V C-V A C-V A L)$ & 2.80 & 5.20 & 1.86 & 91 & 3 & 6 \\
\hline P(VC-VAC) & 1.10 & 2.20 & 2.00 & 87 & 13 & - \\
\hline
\end{tabular}

2) GPC, Apparatus, Waters Associates model $6000 \mathrm{~A}$; column, TSK-GEL; solvent, THF $1.2 \mathrm{ml} / \mathrm{min} 35^{\circ} \mathrm{C}$; sample, $0.4 \mathrm{~g} / 100 \mathrm{ml} 500 \mu l$. Molecular weights were computed from the polystylene calibration curves.

b) Values taken from a catalogue.

Table 2. Structure of silane compounds

\begin{tabular}{ll}
\hline \multicolumn{1}{c}{ Chemical name } & \multicolumn{1}{c}{ Structure } \\
\hline Methyltrimethoxysilane & $\mathrm{CH}_{8} \mathrm{Si}\left(\mathrm{OCH}_{8}\right)_{8}$ \\
Propyltriethoxysilane & $\mathrm{C}_{8} \mathrm{H}_{7} \mathrm{Si}\left(\mathrm{OC}_{2} \mathrm{H}_{6}\right)_{8}$ \\
Pentyltriethoxysilane & $\mathrm{C}_{6} \mathrm{H}_{11} \mathrm{Si}\left(\mathrm{OC}_{2} \mathrm{H}_{6}\right)_{8}$ \\
Octyltriethoxysilane & $\mathrm{C}_{8} \mathrm{H}_{17} \mathrm{Si}\left(\mathrm{OC}_{2} \mathrm{H}_{6}\right)_{8}$ \\
Dodecyltriethoxysilane & $\mathrm{C}_{12} \mathrm{H}_{28} \mathrm{Si}\left(\mathrm{OC}_{2} \mathrm{H}_{6}\right)_{8}$ \\
Octadecyltriethoxysilane & $\mathrm{C}_{18} \mathrm{H}_{37} \mathrm{Si}\left(\mathrm{OC}_{2} \mathrm{H}_{6}\right)_{3}$ \\
\hline
\end{tabular}

た.なお，容媒には，トルェンを用いた．他方は，表面処 理した $r-\mathrm{Fe}_{2} \mathrm{O}_{3}$ に吸着しているシラン化合物の量を，烧 成時の重量減少から算出した。この方法を㛙成法とす 万.

シラン化合物の表面圧一面積 $(\pi-A)$ 曲線は，自記 式 Langmuir-Adam 型膜天种により求めた，展開試料 （洪度䄪 $1 \mathrm{mg} / \mathrm{cm}^{3}$ ペンゼン溶液）を基貿上に展開し， 䄪 10 分間放圈して溶媒を揮無させた後，一定速度 $(25$ $\mathrm{cm}^{2} / \mathrm{min}$ ) で圧皠した.

\section{5 茎䖵角の罗定}

变化 Fe 板を、シラン化合物のトルエン溶液に所定時

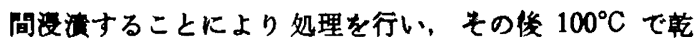
縞し娜定試料とした。

作㱔した試料に，直径 $1 \sim 3 \mathrm{~mm}$ の水滴をのせて，水 滴を徐^に大きくしていく時と，小さくしていく時の水 滴の直径 $\phi$ 及び高さ $\boldsymbol{h}$ をモニターテレビを接統した埕取 り影微鏡を用いて测定し，（1）式によってそれぞれ前進 接触角 $\left(\theta_{\mathbf{2}}\right)$ 及び，後退接触角 $\left(\theta_{\mathrm{r}}\right)$ を求めた．次に得ら れた倠を(2) 式に代入し，接触角を算出した.

$$
\begin{aligned}
& \theta_{2}, \theta_{\mathbf{r}}=\left\{\begin{array}{c}
2 \tan ^{-1}(h / x) \\
\left(\text { たたし } x=\phi / 2, \theta \leqq 90^{\circ}\right) \\
90^{\circ}+\cos ^{-1}\left(\phi h /\left(h^{2}+x^{2}\right)\right) \\
\left(\text { たたし } x=\phi / 2, \theta>90^{\circ}\right)
\end{array}\right. \\
& \theta=\cos ^{-1}\left(\left(\cos \theta_{\mathrm{n}}+\cos \theta_{\mathrm{r}}\right) / 2\right)
\end{aligned}
$$

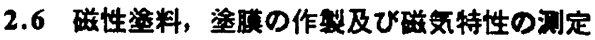

磁性染料は $450 \mathrm{~cm}^{3}$ の容器に溶郕 $107.1 \mathrm{~cm}^{3}$, ハイ ンダー $21.4 \mathrm{~g}$ を入れ、ハインダーを完全に溶解させた 後、磁性粉 $50 \mathrm{~g}$ 及びスチール製ボール $(8 \mathrm{~mm} \phi)$ を加 え，100 時間ボールミル分散することにより作製した。

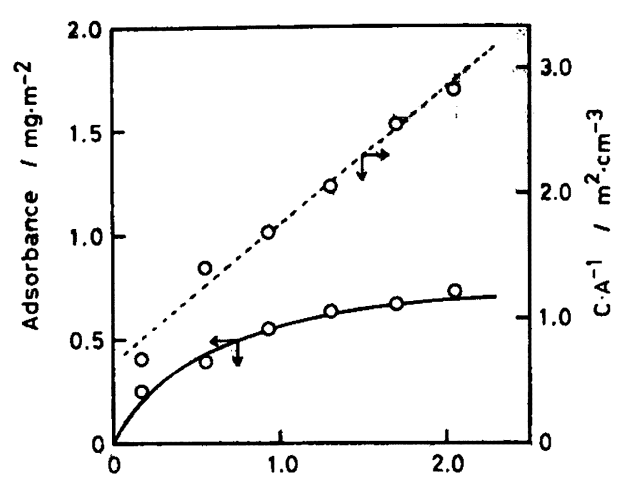

Equilibrium concn. $1 \mathrm{~g} \cdot\left(100 \mathrm{~cm}^{3}\right)^{-1}$

Fig. 1. Adsorption isotherm of octadecyltriethoxysilane on $\gamma-\mathrm{Fe}_{2} \mathrm{O}_{8}$ from toluene solution at $30^{\circ} \mathrm{C}$ and Langmuir plot: —, adsorption isotherm; -..-, Langmuir plot.

なお溶剂には,メチルイソブチルケトン/トルエンの容量 比 $1: 1$ の混合溶媒を用いた。

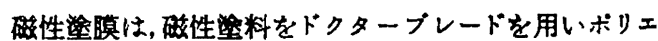
チレンテレフタレートフィルム上に篹布し，染獏が末若 婐のらちにソレノイドコイルにより磁场配向処理 (1000 Oe）を施し，その後 $80^{\circ} \mathrm{C} て ゙$ 軚嬠することにより作製し

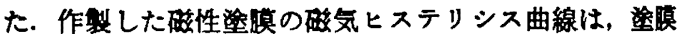
を $1 \times 0.6 \mathrm{~cm}$ 角に切断し，6枚重水で，東英工莱(株) 製振動試料型磁力計 (VSM) により測定した。磁性盗淂 中の粒子の分散・配向性は，磁気ヒステリシスの角型比 より検討した。また充てん性は飽和磁化より検討した.

\section{3 蛣果及ひ宩葲}

\section{1 固/洊及び固/妏界面におけるシラン化合物の民 羊举动}

まずはじめに, $\gamma-\mathrm{Fe}_{2} \mathrm{O}_{3}$ 粒子へのシラン化合物の吸羔

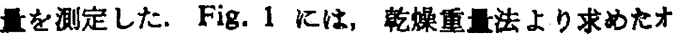
クタデシルトリェトキシシランの $r-\mathrm{Fe}_{2} \mathrm{O}_{3}$ への吸着等 温線及び Langmuir plot を示した. Lanamuir plot が 直線を示すことより，シラン化合物の $\mathrm{r}-\mathrm{Fe}_{2} \mathrm{O}_{8}$ 粒子へ 


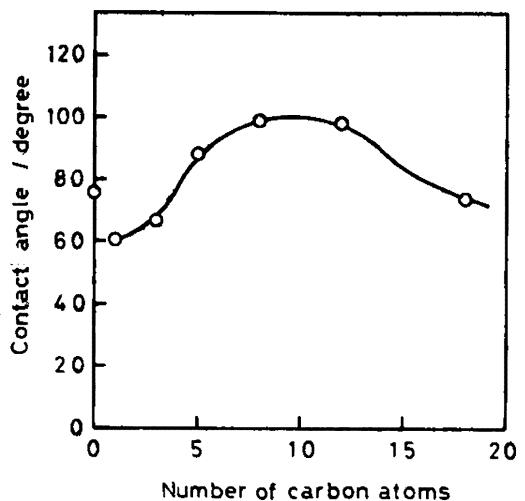

Fig. 2. Relation between the contact angle of iron oxide treated with silane compound and the number of carbon atoms in the alkyl groups. Treating concentration; $1 \mathrm{~cm}^{3} / 80 \mathrm{~cm}^{3}$ toluene; treating time; $24 \mathrm{~h}$.

の吸着挙動は単分子吸着をしていると考えられる.

また，シラン化合物によって表面処理した $\gamma-\mathrm{Fe}_{2} \mathrm{O}_{3}$ 表 面と溶版との親和性に関する知見を得るために，モデル として表面を酸化した Fe 板をシラン化合物で処理し， 水との接触角を测定した. Fig. 2 には，接触角と表面処 理剤であるシラン化合物のすつフルキル鎖孷案数との成 係を示した．図より，フルキル鎖の宸素数の增加に伴い 接触角は增大した.このことから，シラン化合物はシラ ノール基を酸化 $\mathrm{Fe}$ 板表面に向け，眍向吸着し，特に， 炭秦数 10 前後が最すよく配向吸着していると考えられ る. また，炭素数が 18 で接触角が低下した原因につい ては，反応性の低下あるいはフルキル鎖間の凝集力によ

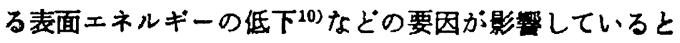
考えられる. 切片の值はトルェンのみに浸清させた時の 接触角を示しているか，この值はアルキル鎖の短いシラ ン化合物を含む系より大きかった：このような結果が得 られた原因としては，系にシラン化合物が存在するとシ ラン化合物が酸化 Fe 板但先吸着するが，トルエンの みの系に括いてはトルェンの吸着が起こるため高い值を 示したと考えられる.

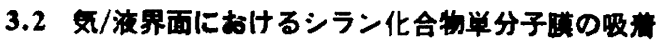 形憼}

従来，我々は，磁性粒子表面が非常に強い親水性を示 すことから，磁性粒子表面を定性的に水表面でおきかえ ることができると考竞，気/水界面における $\pi-A$ 曲線 から，ポリマーの吸着形態を評価してきた4),11) 13).

Fig. 1 より, シラン化合物の $\gamma-\mathrm{Fe}_{2} \mathrm{O}$, 粒子への吸着举 堛は単分子吸着であると考えられる.そこで，本研究に おいても，シラン化合物の吸着形態を $\pi-\boldsymbol{A}$ 曲線から評 価しようとした．Fig. 3 には，オクタデシルトリェト

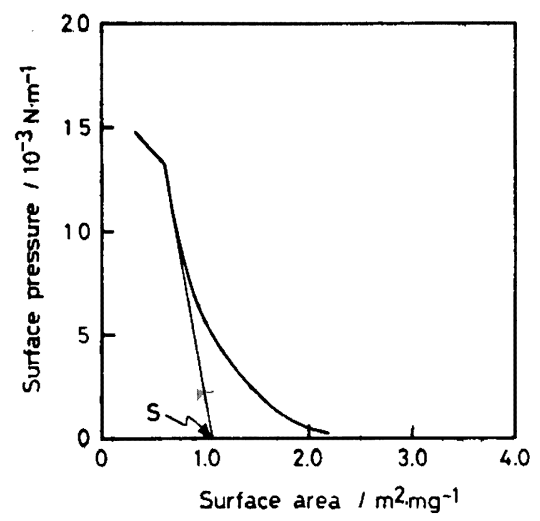

Fig. 3. Surface pressure-area curve of octadecyltriethoxysilane at the air/water interface.

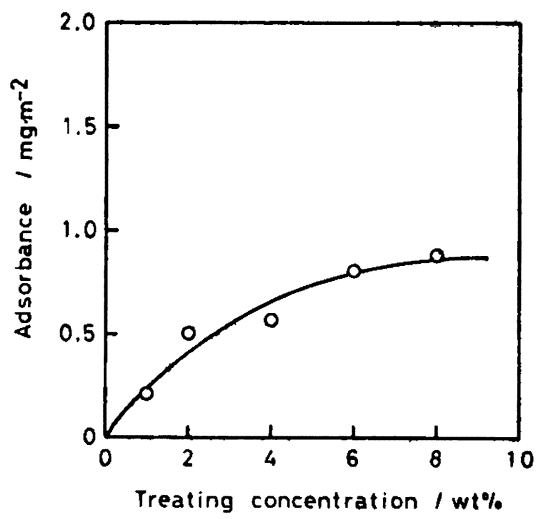

Fig. 4. Relation between the adsorbance of silane compounds on $\gamma-\mathrm{Fe}_{2} \mathrm{O}_{8}$ and the treating concentration of octadecyltriethoxysilane.

キシシランの $\pi$ - $\boldsymbol{A}$ 曲線を示した. 図より明らかなよら に, オクタデシルトリェトキシシランの単分子膜は液体 膨張膜の学動を示した. また，図中 S 点で示したよう に, 空気/水界面にお゙けるオクタデシルトリエトキシシ ランの極限分子占有面積は， $61.4 \AA^{2} /$ Molecule であっ た.

一方, Fig. 1 より得られる 飽和吸着量 $A_{\mathrm{m}}$ から算出 した $\gamma-\mathrm{Fe}_{2} \mathrm{O}_{3}$ 表面でのオクタデシルトリエトキシシラ ンの占有面程は， $69 \AA^{2} /$ Molecule であった. したがっ て，飽和吸着に達している状態では，オクタデシルトリ エトキシシランは $\gamma-\mathrm{Fe}_{2} \mathrm{O}_{8}$ 表面で単分子膜状に最密充 てんした吸着形䈍をとっていると考えられる.

\section{$3.3 \mathrm{r}-\mathrm{Fe}_{2} \mathrm{O}_{3}$-ハインンダー间相互作用}

$\gamma-\mathrm{Fe}_{2} \mathrm{O}_{3}$ 粒子をシラン化合物で表面処理することによ り、ポリマーと粒子との相互作用がどのうに変化する かを、ボリマーの吸着量の変化より評価した。 


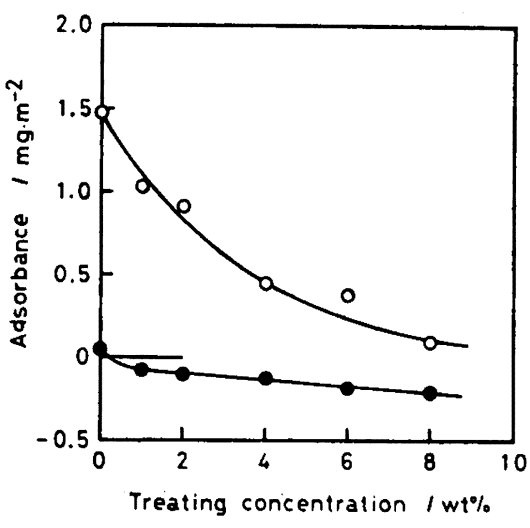

Fig. 5. Relation between the adsorbance of polymers on $\gamma-\mathrm{Fe}_{2} \mathrm{O}_{3}$ and the treating concentration of octadecyltriethoxysilane: $O, P(V C-V A C-V A L)$; ๑, P(VC-VAC)

Fig. 4 には、オクタデンルトリエトキシシランの $r$ $\mathrm{Fe}_{2} \mathrm{O}_{3}$ 上への吸着量と処理湍度との関係を示した. Fig. 1 及び Fig. 4 より明らかなように, オクタデンルトリ エトキシシランの処理渡が約 $8 \mathrm{wt} \%$ において，r$\mathrm{Fe}_{2} \mathrm{O}_{3}$ 表面はすべてシラン化合物の単分子膜で夏われた と考えられる.

Fig. 5 とは，ボリマーの飽和吸着量と处理浱度との 関係を示した，パインダーとして P(VC-VAC-VAL) を用いた場合，処理浱度の增加に伴いボリマーの飽和吸 着量は減少し， $8 \mathrm{wt} \%$ の処理港度においてポリマーの 吸着量は，はぼはになっこのことも，前述の，約 8 wt\% の処理港度において $\gamma-\mathrm{Fe}_{2} \mathrm{O}_{3}$ 粒子表面がすべてシ ラン化合物の単分子膜で嬛われることを示していると考 えられる. また：ハインダーとして P(VC-VAC)を用 いた场合，表面をシラン化合物で処理しないとき，また 処理した時, いずれにおいてもボリマーの吸着は認めら れなかった.

以上の結果より，未処理の $7-\mathrm{Fe}_{2} \mathrm{O}_{8}$ 粒子及びシラン 化合物で表面処理した $\gamma-\mathrm{Fe}_{2} \mathrm{O}_{3}$ 粒子表面でのポリマー の吸着状䳔を推定し，Fig. 6 のよらなモデル図を考案 した. ハインダーとして P(VC-VAC-VAL) を用いた 场合，末処理の $r-\mathrm{Fe}_{2} \mathrm{O}_{3}$ 表面に対しては (A) のよ5に 水酸基をアンカークルーブとしたルーブ・ポイント型の 吸着形的14)をとると考えられる.つぎに，シラン化合物 の $r-\mathrm{Fe}_{2} \mathrm{O}_{3}$ 表面への吸着が飽和に達していない埸合は, (B)のよらKポリマーは $\mathrm{Y}-\mathrm{Fe}_{2} \mathrm{O}_{3}$ 表面に残存している 吸着サイトK吸着するが，シラン化合物の吸着が飽和に 達すると，(C) のよ5にボリマーは吸着しなくなる。 た， :インダーとして P(VC-VAC) を用いた㙁合は， いずれにおいてもボリマーは吸着せず, シラン化合物の みが $\gamma-\mathrm{Fe}_{2} \mathrm{O}_{8}$ 表面に吸着していると考えられる.
以上のように，本節ではシラン化合物の $\gamma-\mathrm{Fe}_{2} \mathrm{O}_{3}$ 表面 での吸着形䔮及びシラン化合物で表面処理した $\gamma-\mathrm{Fe}_{2} \mathrm{O}_{3}$ 表面へのポリマーの吸着挙動を明らかにした。 そこで, 次にシラン化合物の $\gamma-\mathrm{Fe}_{2} \mathrm{O}_{3}$ 粒子表面におけるこのよう な吸着举動が，磁性塗膜 中における $\gamma-\mathrm{Fe}_{2} \mathrm{O}_{3}$ 粒子の分 散・配向・充てん性に及注す影整について娭討した。

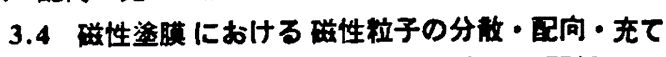
ん性とシラン化合物による表面処理の阅係

Fig. 7 及び Fig. 8 には、フルキル銧がメチル，オクチ ル、オクタデシルの 3 種類のトリフルコキシシランを処 理郕として用いた场合の，磁性染膜の角型比と表面処理

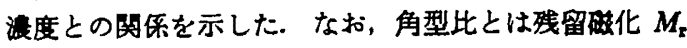
之和和化 $M_{\mathrm{a}}$ との比 $M_{\mathrm{s}} / M_{\mathrm{a}}$ で，この値が 1 K近い性 と䤠膜中で粒子がよく配向していることを示す日). ハィ ンダーとして P(VC-VAC) を用いた揚合，いずれのシ ラン化合物を用いたときにおいてす，2wt\% までは表 面処理浸度の增大とともに急擞に角型比は向上し，それ 以上ではほぼー定になった。また、ハインダーとして P(VC-VAC-VAL) を用いた氛は，未処理の状態にお いても親水性官能基の妙果 が：シラン化合物で处理することによりさらに向上が窥 められ, 約 $2 \mathrm{wt} \%$ の処理㴤度でビーク值が得られた。

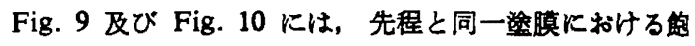
和磁化と表面処理港度の成係を示した．P(VC-VAC)を ハインダーとして用いた场合，いずれのシラン化合物を

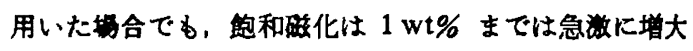
し、それ以上の港度ではゆるやかに向上した。また。 P(VC-VAC-VAL) をハインンターとして用いた場合は， 角型比と同様に和磁化においても約 $2 \mathrm{wt} \%$ の処理港 度でピーク値が得られた。これらの結果と前節の結果を 考えあわせると，シラン化合物とパインダーとが， $\mathrm{Fe}_{2} \mathrm{O}_{3}$ 表面においては注同程度混合吸着した㘯合，粒子 の分散性が取る向上すると考えられる.

Fig. 11 には，磁性㳂膜の角型比と表面処理都である シラン化合物のもつフルキル鎖の炭桑数の関保を示し た. また，Fig. 12 Кは，磁性盗膜の的磁化とシラン 化合物のるつフルキル鎖の炭素数の成係を示した. 処理 港度は $2 \mathrm{wt} \%$ である.なお，切片の值は，末処理 $r$. $\mathrm{Fe}_{2} \mathrm{O}_{3}$ におけるそれぞれの角型比および和磁化を示し た. P(VC-VAC-VAL) または P(VC-VAC) いずれを ハインターとして用いた场合においても，炭菜数の增加 に伴い角型比及び飽和破化徐々に向上した．またそれ らは，炭素数が 8 以上ではぼー定となった。

以上の結果より，P(VC-VAC-VAL) をパインダーと して用いた场合は、シラン化合物とポリマーの混合吸着 により分散性が向上し、オクタデシルトリェトキシシラ ンにおいては，ほぼ同程度混合吸着した時, 最も分散性 が高かった、また，P(VC-VAC)をハインダーとして 


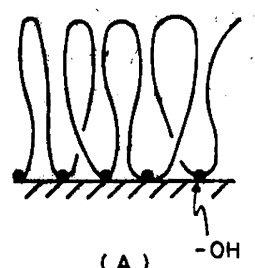

(A)

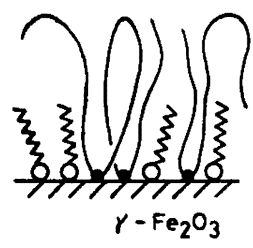

(B)

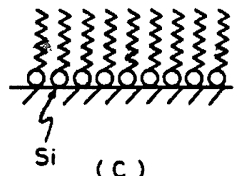

(C)

Fig. 6. Schematic picture of the adsorbed polymer and silane compound at the solvent $/ \gamma$ $\mathrm{Fe}_{2} \mathrm{O}_{2}$ interface. Treating concentration: (A), untreated; (B), $2 \mathrm{wt} \% ;(C), 8 \mathrm{wt} \%$. - P(VC-VAC-VAL), $\sim 0$; silane compound.

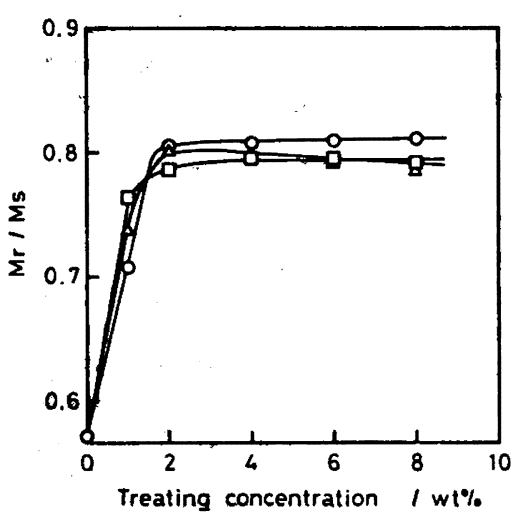

Fig. 7. Relation between the squareness and the treating concentration of silane compound: $\square$, methyltrimethoxysilane; $\triangle$, octhyltriethoxysilane; $O$, octadecyltriethoxysilane. Binder, P(VC-VAC).

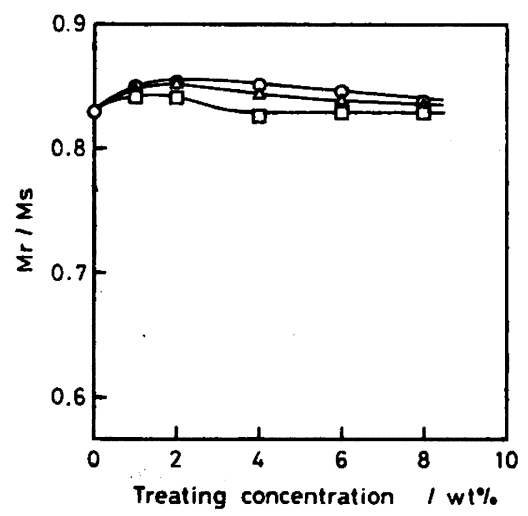

Fig. 8. Relation between the squareness and the treating concentration of silane compound: $\square$, methyltrimethoxysilane; $\Delta$, octhyltriethoxysilane; 0 , octadecyltriethoxysilane. Binder, P(VC-VACVAL).

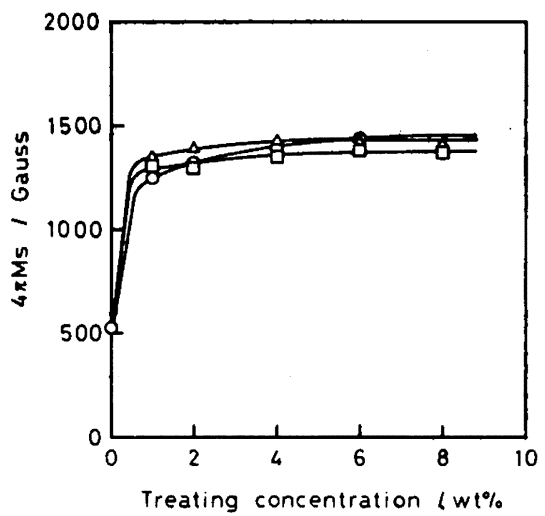

Fig. 9. Relation between the saturated magnetization and the concentration of silane compound. $\square$, methyltrimethoxysilane; $\Delta$, octhyltriethoxysilane; $O$, octadecyltriethoxysilane. Binder, P(VCVAC).

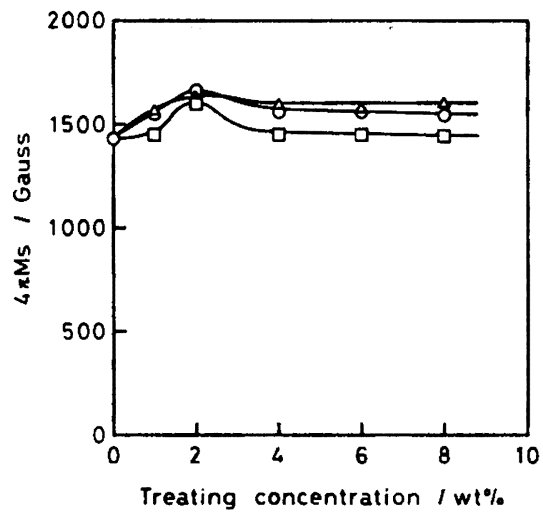

Fig. 10. Relation between the saturated magnetization and the concentration of silane compound: $\square$, methyltrimethoxysilane; $\Delta$, octhyltriethoxysilane; $O$, octadecyltriethoxysilane. Binder, P(VCVAC-VAL). 


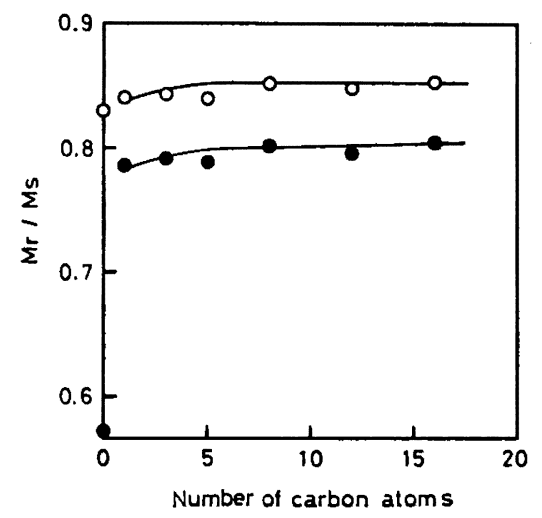

Fig. 11. Effect of the number of carbon atoms in alkyl groups on the squareness: $O, P(V C-V A C-$ VAL); $\bullet, P(V C-V A C)$. Treating concentration, $2 \mathrm{wt} \%$.

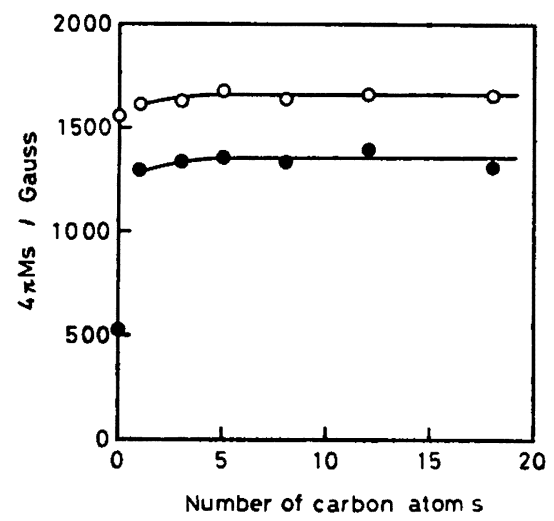

Fig. 12. Effect of the number of carbon atoms in alkyl groups on the saturated magnitization: $\mathrm{O}, \mathrm{P}(\mathrm{VC}-\mathrm{VAC}-\mathrm{VAL}) ; \bullet, \mathrm{P}(\mathrm{VC}-\mathrm{VAC})$. Treating concentration, $2 \mathrm{wt} \%$.

用いた場合は、ボリマーが磁性粒子表面に吸着しないた め, シラン化合物の吸着のみが粒子の分散性に影響を与 えたと考えられる.

\section{4 結}

フルキル鎖をるつシラン化合物の $\gamma-\mathrm{Fe}_{2} \mathrm{O}_{3}$ への吸着 は， Langmuir 型を示した. $\gamma-\mathrm{Fe}_{2} \mathrm{O}_{3}$ 表面をシラン化合 物で処理することにより，P(VC-VAC)をハインダーと して用いた场合，粒子の分散性は処理浱度が約 $2 \mathrm{wt} \%$
までは急敖に向上し，それ以上ではほぽー定となった。 一方，P(VC-VAC-VAL) をパインダーとして用いた場 合は，粒子の分散性は約 $2 \mathrm{wt} \%$ でピーク值が得られ た. また，シラン化合物のるつアルキル銧については， いずれのポリマーを用いた場合であ, 炭菜数の增加に伴 い粒子の分散性は向上し，その龙菜数が 8 以上でほぼー 定になった.

$\gamma-\mathrm{Fe}_{2} \mathrm{O}_{3}$ の分散性に成して以上の結果が得られたこと を、シラン化合物及びポリマーの混合吸着形腎より説明 した.

付婄本研究壮, 旭硝子工莱技術奖励会の研究助成 のもとに行われたものであり、ここに杞して感期しま 广. 本研究仕第 31 回高分子研究発表会 (1985 年 7 月 12 日，神戸）において発表したものである。

\section{文视}

1）角谷管二，端山文忠，松本恒隆，日本接着協会 喆, 17, 155 (1981).

2）たとえば，杤原重三，色材，49，612 (1976).

3) 角谷留二, 中前勝彦, 海谷誠治, 端山文忠, 烃 本恒隆, 漓分子論文集, 37, 49 (1978).

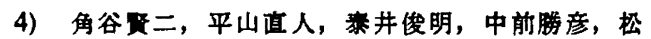
本恒隆，高分子站女集，41，273 (1984).

5) 角谷雪二, 泰井伐明, 中前勝彦, 松本桓隆, 高 分子論文集, 38, 139 (1981).

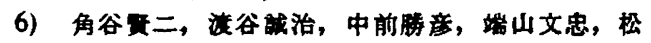

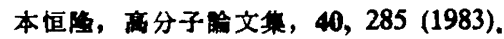

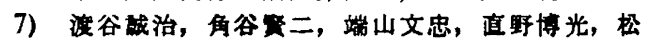
本恒隆，高分子的文集，35, 565 (1978).

8) K. Sumiya, N. Hirayama, F. Hayama, and T. Matsumoto, IEEE. Trans. Magn., MAG20, 745 (1984).

9) 竹内光二, 士星栄吾, 高檑 浩, 表面化学, 3 [2], 65 (1982).

10）大森英三,“アクリル酸エステルとそのポリマ - [II]", 昭光堂, 東京, (1975) p. 113.

11) K. Nakamae, K. Sumiya, K. Taii, and T. Matsumoto, J. Polym. Sci., Polym. Symp., 71, 109 (1984).

12）中前勝彦，身谷俊一，藤村保夫，昖本桓隆，日 本接揞会誌, 17, 312 (1981).

13）藤村保夫, 酒井五十治, 畑田元義, 岡田紀夫, 中前勝彦，松本恒隆，高分子碖文集，37，29 (1980).

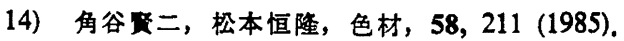


Adsorption Behavior of Alkyl Silane Compounds on Magnetic Particles-Packing and Orientation Behavior of Particles in Magnetic Coatings*

Katsuhiko NakamaE*1, Satoshi Tanigawa*1, Naoto HiRayama*1, Kenji SumiYa*1, and Tsunetaka MatsuMoTo*1

*Studies on Recording Mganetic Materials and Magnetic Composites. XII

*1 Department of Industrial Chemistry, Faculty of Engineering, Kobe University (1, Rokko dai-cho, Nada-ku, Kobe, 657 Japan)

$\gamma-\mathrm{Fe}_{2} \mathrm{O}_{8}$ was treated with alkyl silane compounds. The dispersibility of this treated $\gamma-\mathrm{Fe}_{2} \mathrm{O}_{8}$ was investigated.

The following results were obtained. 1) Absorption of alkyl silane compounds on $\gamma-\mathrm{Fe}_{2} \mathrm{O}_{8}$ was Langmuir type. 2) The $\gamma-\mathrm{Fe}_{2} \mathrm{O}_{3}$ treated with alkyl silane compounds had high dispersibility in magnetic paints. 3) The highest dispersibility was obtained for ca. $2 \mathrm{wt} \%$ of silane compounds $v s . \gamma-\mathrm{Fe}_{2} \mathrm{O}_{8}$ and for alkyl chains of silane compounds which contain more than 8 carbons.

KEY WORDS $\gamma-\mathrm{Fe}_{2} \mathrm{O}_{3}$ / Alkyl Silane Compounds / Dispersibility / Magnetic Paints /

(Received August 8, 1985: Accepted September 25, 1985)

[Kobunshi Ronbunshu, 43 (2), 63-69 (1986)] 